\title{
Thyroid hormone induction of keratin genes: a two-step activation of gene expression during development
}

\author{
Peter M. Mathisen and Leo Miller \\ Laboratory for Cell, Molecular, and Developmental Biology, Department of Biological Sciences, University of Illinois at \\ Chicago, Chicago, Illinois 60680 USA
}

\begin{abstract}
To determine the mechanism of action of the thyroid hormone triiodothyronine $\left(\mathrm{T}_{3}\right)$ during metamorphosis of the amphibian epidermis, we have investigated the developmental activation of the 63-kD keratin genes in the frog Xenopus laevis. These genes code for three closely related keratins that first appear in the larval epidermis and accumulate during metamorphosis to become the most abundant proteins in the adult epidermis. We report here that the $63-\mathrm{kD}$ keratins and their mRNAs first appear at stages 48-52. The level of 63-kD keratin gene expression remains relatively low until stage 56 and then increases dramatically. Quantitative analysis of the concentration of 63-kD keratin mRNA demonstrates low levels until stage 55/56, followed by an increase greater than 300 -fold from stage $55 / 56$ to the adult. Each adult cell contains approximately 55,000 molecules of the 63-kD keratin mRNAs. $T_{3}$ is not required for the initial activation of the 63-kD keratin genes, but highlevel expression is absolutely dependent on $\mathrm{T}_{3}$. High-level expression is prevented by propylthiouracil, which inhibits thyroid hormone synthesis and can be induced precociously both in vivo and in vitro with exogenous $T_{3}$ as early as stage 48 , but not prior to that time. Thus, the full activation of the $63-\mathrm{kD}$ keratin genes during development requires two regulatory steps, one independent and one dependent on $T_{3}$.
\end{abstract}

[Key Words: Development; gene expression; keratins; metamorphosis; thyroid hormone; Xenopus]

Received May 18, 1987; revised version accepted September 23, 1987.

Metamorphosis in amphibians is absolutely dependent on thyroid hormones. Virtually every tissue of the larva responds to the thyroid hormone triiodothyronine $\left(T_{3}\right)$ with diverse biochemical and morphological changes. Transplantation experiments have established that each tissue is preprogrammed to respond to $T_{3}$ in a characteristic fashion (for review, see Frieden and Just 1970). Thus, $T_{3}$ is responsible for coordinating the multiple metamorphic changes occurring throughout the tadpole. Like other hormones, $\mathrm{T}_{3}$ acts by eliciting unique programs of differentiation, which depend on the intrinsic characteristics of the responding tissues. Unlike most hormones, however, $T_{3}$ triggers irreversible changes that ultimately convert larval tissues to adult tissues at metamorphosis.

The mechanism of $T_{3}$ action during metamorphosis has been analyzed extensively using morphological and biochemical parameters to assay the $T_{3}$ effects. It has been shown that $T_{3}$ acts directly on numerous tissues and not via another endocrine hormone or systemic factor (Kollros 1959). Although other endocrine hormones have been implicated in modifying the $T_{3}$ response, it has not been determined how or at what level these interactions occur (White and Nicoll 1981). There is substantial evidence from work with mammalian cells that $T_{3}$ activates transcription by binding to a nuclear receptor, which then interacts directly with the regulatory sequences of specific genes (Casanova et al. 1985; Crew and Spindler 1986). Thus, $\mathrm{T}_{3}$ is thought to act like a steroid hormone in mammals. In amphibians, it has been shown that $T_{3}$ interacts with a nuclear receptor in various tissues and that the morphological changes induced by $T_{3}$ are dependent on changes in RNA and protein synthesis (Frieden and Just 1970; Galton 1983). As yet, however, individual $T_{3}$-responsive genes of amphibians have not been analyzed directly at the molecular level. In this paper we describe a model system for such an analysis.

The conversion of the larval epidermis to the adult epidermis at metamorphosis provides an excellent model system for analyzing the mechanism of $\mathrm{T}_{3}$ action. The larval epidermis, which is bilayered and unkeratinized, begins to stratify and keratinize during metamorphosis (Nieuwkoop and Faber 1967). This transformation is $\mathrm{T}_{3}$-controlled, as shown by the precocious induction of adult skin in premetamorphic larva when $T_{3}$ is added to the water or when $\mathrm{T}_{3}$-containing pellets are implanted into larval skin (Kollros and Kaltenbach 1952). It has been shown that the conversion of larval skin to adult skin in Xenopus is correlated with the appearance of adult keratins and the loss of embryo keratins (Ellison et al. 1985; Sargent et al. 1987). The most abundant keratins in the adult epidermis are three closely related 63-kD polypeptides (Hoffmann et al. 1985). We have 
shown that the $63-\mathrm{kD}$ keratins first appear in premetamorphic tadpoles and accumulate to become the major proteins of the adult epidermis (Ellison et al. 1985). In this report we examine the role of $T_{3}$ in the activation of $63-\mathrm{kD}$ keratin gene expression and propose that full activation of these genes requires two regulatory steps, the first step being independent of $T_{3}$, and the second dependent on $T_{3}$.

\section{Results}

Appearance of the 63-kD keratins during development

In the adult epidermis, the $63-\mathrm{kD}$ (type II) keratins are the most abundant proteins. Using Coomassie Blue staining, we demonstrated previously that these keratins are present in the larval epidermis at stage 52 (Ellison et al. 1985), but we did not determine when the $63-\mathrm{kD}$ keratin genes are first expressed. To determine when the $63-\mathrm{kD}$ keratins are first synthesized, we isolated the head skins of larvae at different developmental stages and incubated them with $\left[{ }^{35} \mathrm{~S}\right]$ methionine. Two examples of labeled cytoskeletal proteins are shown in Figure 1. The $63-\mathrm{kD}$ keratins are first detected as a faint band in the skin of stage 48 larvae (Fig. 1A). They are also labeled in control larvae at stage 48 in the two ex-

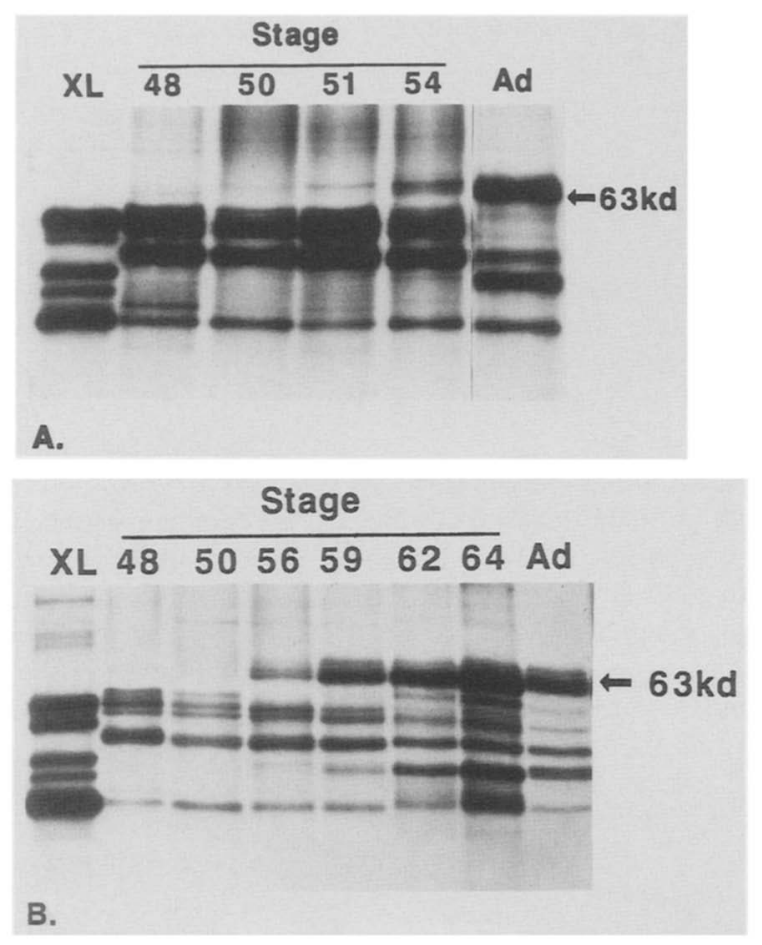

Figure 1. Appearance of the $63-\mathrm{kD}$ keratins during development. Skin was dissected from the heads of tadpoles at various stages and labeled with $\left[{ }^{35} \mathrm{~S}\right]$ methionine. $(A)$ Overexposed autoradiograph demonstrating leaky expression between stages 48 and 52. $(B)$ Developmental profile showing high-level expression from stage 56 through metamorphosis. (XL) A nonepidermal, epithelial cell line that does not synthesize adult keratins; (Ad) adult epidermis. periments shown in Figure 6. However, the $63-\mathrm{kD}$ band was not visible in some autoradiographs even if the $\mathrm{X}$-ray film was overexposed. In four out of seven different experiments, a low level of $63-\mathrm{kD}$ keratin synthesis was detected in in vivo skin preparations of stages 48-50 larvae, and in all cases, a clear band was observed at stage 51 . Further evidence for the expression of the $63-\mathrm{kD}$ keratin genes at stage 48 , at both the protein and mRNA levels, was obtained from in vitro studies of skin explant cultures (P.M. Mathisen and L. Miller, in prep.). The in vitro results were much more consistent than the in vivo data described above. In all in vitro experiments, the expression of the $63-\mathrm{kD}$ keratin genes was detected in untreated skin cultures at stage 48 (as shown in Fig. $5 \mathrm{~B}$ ). Thus, the $63-\mathrm{kD}$ keratin genes display a "leaky" expression at stage 48 (for $63-\mathrm{kD}$ keratin mRNA quantitation, see below).

After stage 48 , the synthesis of the $63-\mathrm{kD}$ keratins increases slowly (Fig. 1A), until stage 56 at which time the relative rate of synthesis increases dramatically (Fig. 1B). The $63-\mathrm{kD}$ keratins become the most abundant keratins synthesized in the epidermis during metamorphic climax (stages 58-65). The increase in 63-kD keratin synthesis, beginning at stage 56 and continuing throughout metamorphosis, is correlated with the initiation of epidermal stratification and keratinization (Nieuwkoop and Faber 1967) and the first appearance of thyroid hormones in the blood (Buscaglia et al. 1985). Thus, the low level of $63-\mathrm{kD}$ keratin synthesis from stage 48 to stage 56 appears to be occurring in the absence of $\mathrm{T}_{3}$. Interestingly, the $63-\mathrm{kD}$ keratins are also synthesized in the tail skin, although the entire tail is destroyed during metamorphic climax. The synthesis of the $63-\mathrm{kD}$ keratins begins at a later stage in the tail epidermis and never attains the high rates observed in the head and body epidermis. However, in vitro studies (P.M. Mathisen and L. Miller, submitted) have shown that exogenous $T_{3}$ can induce high-level expression of the 63-kD keratins in tail epidermis. To eliminate the variability due to the progressive anterior-posterior activation of $63-\mathrm{kD}$ keratin synthesis, only head skin was used in the keratin protein synthesis experiments reported in this paper.

\section{Appearance of the 63-kD keratin mRNAs during development}

To determine whether the changes in $63-\mathrm{kD}$ keratin synthesis are controlled at the mRNA level, RNA was isolated from the skin of larvae at different stages and the $63-\mathrm{kD}$ keratin mRNA content was measured. Unlike the experiments on keratin protein synthesis in which only head skin was used, the RNA was isolated from the skin of the entire embryo (see Materials and methods). The $63-\mathrm{kD}$ keratin mRNA content of total skin RNA was determined by hybridizing it to probes prepared from cDNAs obtained from Dr. Werner Hoffmann (Hoffmann et al. 1985). In that study, three different cDNAs (pUF23, pUF132, and pUF164) were shown to hybrid-select mRNAs coding for $64-\mathrm{kD}$ keratins (our molecular weight estimate of these proteins is $63 \mathrm{kD})$. Although 
they found three 64-kD keratins in adult skin, the three cDNAs could not be assigned to individual keratins because of extensive cross hybridization of the three cDNAs and mRNAs. The small differences between the cDNAs pUF23 and pUF164 suggest that they may be polymorphic variants of the same gene (Sargent et al. 1987). To establish that a 3 '-end subclone of pUF164 (pM7), which we prepared in an attempt to assay individual mRNAs, hybridizes to mRNA for the $63-\mathrm{kD}$ keratins, we hybrid-selected total adult epidermal RNA with this subclone and translated the bound RNA in a reticulocyte lysate. The results for pUF23 and pM7 are shown in Figure 2. Both of these cDNAs select mRNAs coding for proteins that coelectrophorese with the $63-\mathrm{kD}$ keratins. However, even with the $3^{\prime}$-end fragment of pUF164, the cDNA with the longest $3^{\prime}$-nontranslated region, hybridization to all $63-\mathrm{kD}$ keratin mRNAs occurred (see below). Thus, the mRNA data presented below (Figs. 3, 4, and 7), using a cRNA probe prepared from pM7 (see Materials and methods for the preparation of the probes), reflect the cumulative amount of all 63-kD keratin mRNAs. To assay individual transcripts of the pUF164 gene, it was necessary to carry out RNase protection experiments (Fig. 8).

The results of slot-blot analysis with different staged larval skin RNA preparations, hybridized to cRNA probes, indicate that high concentrations of $63-\mathrm{kD}$ keratin mRNAs are present at stage 57 but not at stage 55/56 (Fig. 3A). In other experiments high-level expression was seen in older stage 56 larvae (data not shown). Thus, the high-level synthesis of the 63-kD keratins from stage 56 through metamorphosis is correlated with high concentrations of the cognate mRNAs (Fig. 3A). Internal controls using probes for rRNA (pMll) and an

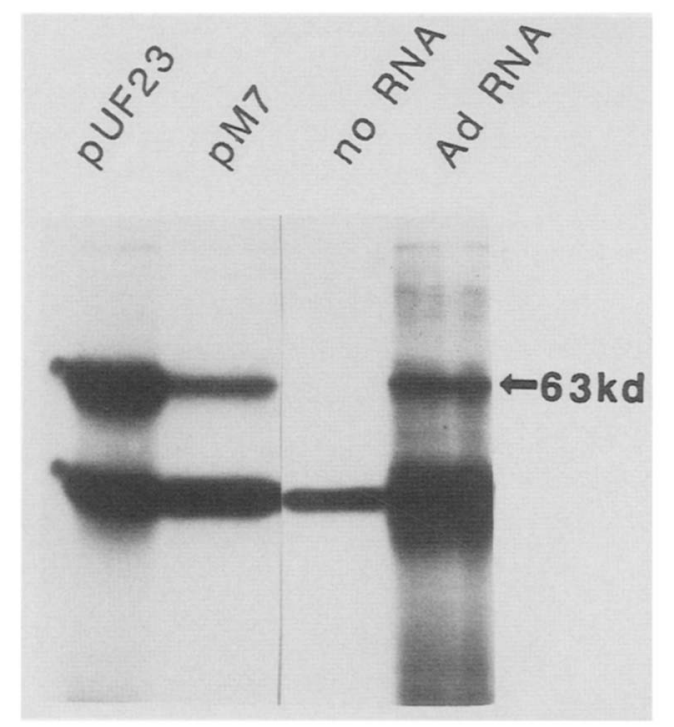

Figure 2. Translation products of hybrid-selected RNAs. (pUF23) A cDNA that hybrid-selects the 63-kD keratin mRNA (Hoffmann et al. 1985); (pM7) a 3'-end subclone of pUF164; (Ad RNA) total adult epidermal RNA. The lower band is an endogenous protein of the reticulocyte lysate, which is labeled with $\left[{ }^{35} \mathrm{~S}\right]$ methionine in the absence of RNA. adult type I keratin mRNA (pM12) establish that equal amounts of RNA were loaded in all slots. The adult type I keratin probe (pM12) recognizes a 4.2-kb RNA band in XL-177 cells and a 1.85-kb RNA in adult epidermal cells (data not shown). The cross-reaction of this probe with the RNAs of larval epidermal cells and XL-177 cells is most likely due to the homology between their type I keratins. In any event, the concentration of RNA recognized by this probe remains constant throughout development (Fig. 3A). The specificity of the hybridization between the probe and 63-kD keratin mRNAs is demonstrated by the lack of hybridization to RNA of the cell line XL-177, which synthesizes type II keratins but not the 63-kD keratins (Fig. 1). To detect low levels of 63-kD keratin mRNA, the autoradiographs were overexposed. Such overexposures of slot blots also brought up background as indicated by positive signals with XL-177 RNA and sometimes yeast tRNA. Consequently, Northern analysis of the RNA was carried out. The cRNA probe for the $63-\mathrm{kD}$ keratin mRNAs prepared from pUF164 recognizes a 2.4-kb RNA band in both adult and larval skin RNA (Fig. 3B). An identical sized band is also recognized by pUF23 and pUF132 (Hoffmann et al. 1985). In agreement with the slot-blot analysis (Fig. 3A), high-level concentrations of the $63-\mathrm{kD}$ keratin mRNAs are detected at stage 57 , as shown in Figure 3B, and at stage 56 in other experiments. Overexposure of the autoradiographs from different Northern blots indicates that in different experiments, a positive signal appears between stages 48 and 52 (Fig. 4). The earliest stage where an accurate quantitation was possible was stage 52 (see below). To determine whether the absence of a positive signal with pM7 was due to the inability of this probe to hybridize to mRNAs of other $63-\mathrm{kD}$ keratin genes, a probe for the highly conserved $\alpha$-helical coding portion of the mRNA was prepared. The $\alpha$-helical coding region of the Xenopus type II keratin genes is highly conserved (Hoffmann et al. 1985), as demonstrated previously for the type II keratin genes of other species (Fuchs and Marchuk 1983). Thus, the conserved sequence probe should recognize all mRNAs of the $63-\mathrm{kD}$ keratin genes, as well as other type II keratin mRNAs. The results obtained with the conserved sequence probe (pM14) and the $3^{\prime}$ probe of pUF164 (pM7) were virtually identical with respect to the appearance of the 63-kD keratin mRNAs, suggesting that pM7 and pM14 recognize all of the $63-\mathrm{kD}$ keratin mRNAs (Figs. 4 and 7).

\section{Quantitation of 63-kD keratin mRNAs in total cellular RNA}

The amount of 63-kD keratin mRNA in adult and larval RNA samples was determined by reference to a standard curve generated with known amounts of pM7 sense RNA (see Materials and methods). The concentration of $63-\mathrm{kD}$ keratin mRNA was calculated to be approximately $4500 \mathrm{pg} / \mu \mathrm{g}$ of total adult epidermal RNA. This value corresponds to $3.3 \times 10^{9}$ molecules of mRNA or approximately 55,000 mRNA molecules per adult epidermal cell (Table 1). The amount of $63-\mathrm{kD}$ keratin 


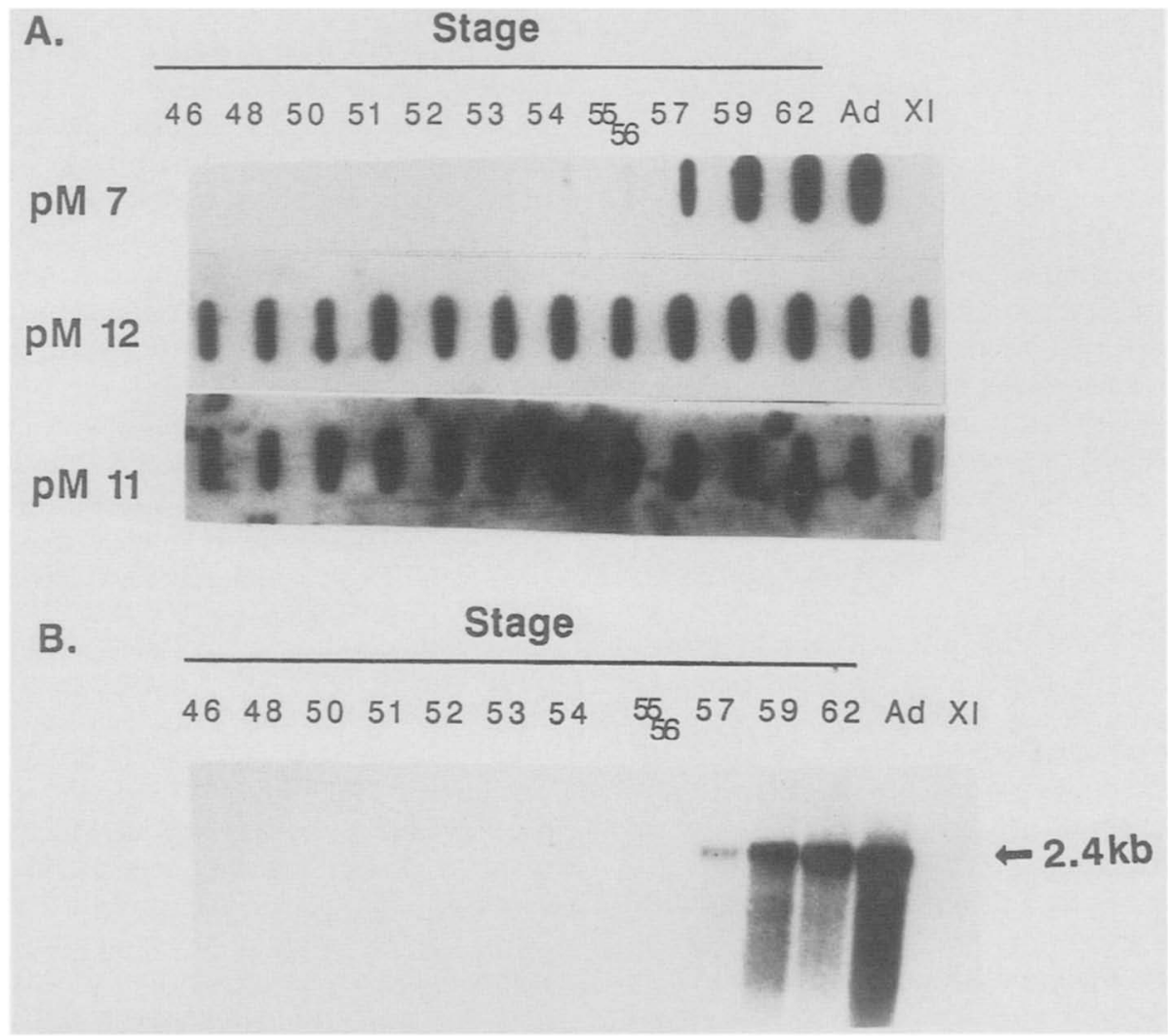

Figure 3. Appearance of the $63-\mathrm{kD}$ keratin mRNAs during development. RNA isolated from the skin of larvae of different stages was slot-blotted onto a GeneScreen Plus filter $(A)$ or electrophoresed through a formaldehyde-agarose gel before blotting onto a GeneScreen Plus filter $(B) .(A)$ The filters were hybridized individually with cRNA probes prepared from the clones indicated. (pM7) A 3 '-end subclone of pUF164, used to detect the 63-kD keratin mRNAs; (pM12) a subclone of pUF29, which detects type I keratin mRNAs; (pM11) a subclone of pXlr11, which detects $18 \mathrm{~S}$ and $28 \mathrm{~S}$ rRNA. The Northern blot in $B$ was hybridized with a cRNA prepared from pM7. Stage 55/56 RNA was obtained from a mixture of stage 55 and early stage 56 larvae. Exposure time was 4 hr.

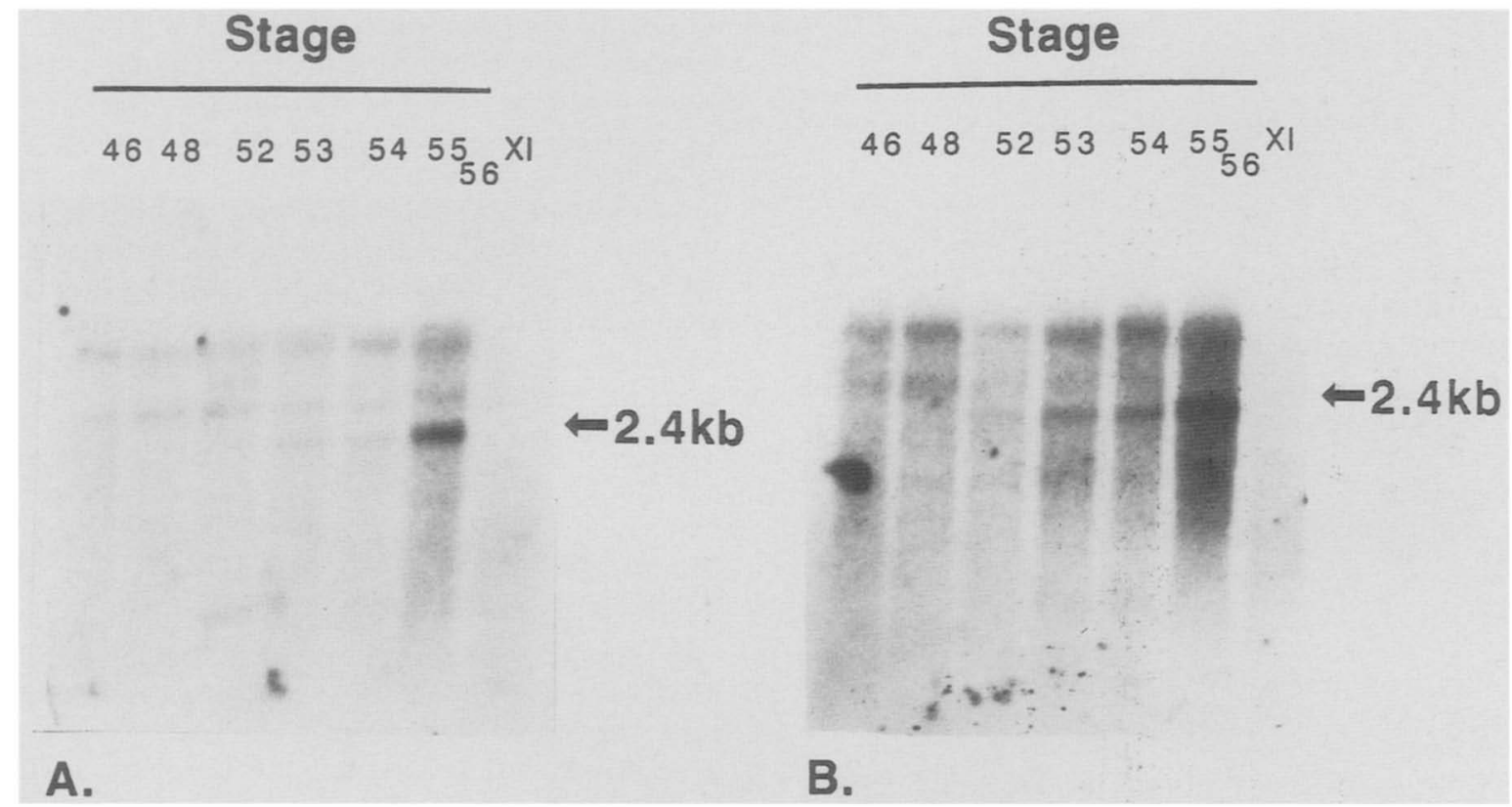

Figure 4. Northern blot analysis of 63-kD keratin mRNA appearance in premetamorphic tadpoles. RNA (5 $\mu \mathrm{g}$ ) from stages 46 to $55 / 56$ larval skin was hybridized with cRNA prepared from pM7 $(A)$ or pM14 (B). (pM14) A subclone of pUF164, which contains the highly conserved coding region for the $\alpha$-helical portion of the type II keratins. Exposure time was increased to $72 \mathrm{hr}$ to visualize the 2.4-kb mRNA band. 
Table 1. Concentration of $63-k D$ keratin $m R N A$ during development

\begin{tabular}{lcc}
\hline Stage & $\begin{array}{l}\text { Time after } \\
\text { fertilization } \\
\text { (days) }\end{array}$ & $\begin{array}{l}\text { mRNA content } \\
\text { (pg/ } \mu \text { of } \\
\text { total RNA) }\end{array}$ \\
\hline 52 & 21 & 1 \\
53 & 24 & 4 \\
54 & 26 & 11 \\
$55 / 56$ & 38 & 13 \\
57 & 41 & 300 \\
62 & 49 & 3500 \\
Adult & - & 4500 \\
\hline
\end{tabular}

An estimate of $17 \mathrm{pg}$ of RNA per cell was made from RNA isolated (by $\mathrm{CsCl}$ centrifugation) from a known number of cultured stage 54 epidermal cells. Assuming similar levels of RNA in larval and adult cells, each adult cell would contain approximately 55,000 molecules of $63-\mathrm{kD}$ keratin mRNA.

mRNA increased slightly from stages 52 to $55 / 56$ and increased more than 300 -fold from stages $55 / 56$ to the adult (Table 1). Overall, the concentration of $63-\mathrm{kD}$ keratin mRNA increases over three orders of magnitude during the transition from basal-level synthesis to highlevel synthesis.

\section{Effects of $T_{3}$ on the synthesis of the 63-kD keratins and $m R N A s$}

In a previous report, Reeves (1977) demonstrated that an immunoprecipitatable keratin typical of adult skin appeared for the first time at stages 54-55. Furthermore, he showed that this adult keratin could be activated precociously by $T_{3}$ at stages $50-52$ but not before that time. Based on its developmental appearance and estimated molecular mass of $69 \mathrm{kD}$, we believe that the adult keratin studied by Reeves corresponds to the $63-\mathrm{kD}$ keratin we have identified using more sensitive techniques. Because small amounts of the $63-\mathrm{kD}$ keratins are synthesized at stage 48 (Figs. 1, 5B, and 6), the report by Reeves (1977) that $T_{3}$ precociously activates the $63-\mathrm{kD}$ keratins at stages $50-52$ must be reevaluated. We therefore investigated the effects of $T_{3}$ on the synthesis of the $63-\mathrm{kD}$ keratins. Larvae of various stages were treated with $T_{3}$ $\left(10^{-8} \mathrm{M}\right)$ until control larvae reached stage 47 or 48 and their head skin was isolated and incubated with $\left[{ }^{35} \mathrm{~S}\right] \mathrm{me}$ thionine. Analysis of the keratins synthesized by larvae in the presence or absence of $T_{3}$ demonstrated that the $63-\mathrm{kD}$ keratins could not be detected before stage 48 , even if the larvae were $\mathrm{T}_{3}$ treated for 4 or 5 days (Fig. 5A; Table 2). Normally, a 4-day $T_{3}$ treatment at stage 48 was sufficient to induce high-level synthesis (Table 2 ).

Once the larvae reach stage 48 , the epidermis becomes competent to respond to $T_{3}$. When stage 41 and 46 larvae are treated with $\mathrm{T}_{3}$ for 7 days, high-level synthesis of the $63-\mathrm{kD}$ keratins is induced, but the stage 46 larvae synthesize greater quantities of the 63-kD keratins (Fig. 6). During this time all larvae reach stage 48 , but the stage 46 tadpoles spend 4 days at stage 48 , whereas the stage 41 tadpoles spend only 3 days at this stage. If $T_{3}$ is present on the first day and the larvae are then trans- ferred to hormone-free water for 6 days, the stage 41 and 46 larvae begin low-level synthesis of the $63-\mathrm{kD}$ keratins, but $\mathrm{T}_{3}$ does not increase the synthesis above the levels found in untreated larvae (Fig. 6). These results demonstrate that the relative amount of $63-\mathrm{kD}$ keratin synthesis increases directly with the time spent at stage 48 in the presence of $T_{3}$ (for further data, see Table 2) and high-level synthesis that normally begins at stage 56 (Fig. 1) can be induced precociously by $T_{3}$ at stage 48 (Fig. 6). To establish that $T_{3}$ is required for high-level induction of the $63-\mathrm{kD}$ keratins, stage 45 larvae were treated with $0.005 \%$ propylthiouracil (PTU) to inhibit endogenous thyroid hormone synthesis. After 3 months, PTU-treated larvae developed to stage 54, the same stage reached by hypophysectomized and thyroidless larvae (Dodd and Dodd 1976), whereas untreated siblings completed metamorphosis. The PTU-treated larvae do not initiate high-level synthesis of the $63-\mathrm{kD}$ keratins, whereas larvae removed from PTU at stage 54 and allowed to develop to stage 56 synthesize the $63-\mathrm{kD}$ keratins at high levels (data not shown).

The precocious induction of high-level $63-\mathrm{kD}$ keratin synthesis by $T_{3}$ at stage 48 has also been demonstrated in vitro. Explants of larval skin were plated on Matrigel-coated culture dishes and grown in Leibovitz media without fetal calf serum (Materials and methods). Skin from stage 43 larvae (Fig. 5B) was cultured in vitro for 6 days, by which time normal embryos were at stage 48 . In agreement with the in vivo results, $T_{3}$ induced highlevel $63-\mathrm{kD}$ keratin synthesis in these skin explants. It is noteworthy that the $63-\mathrm{kD}$ keratins are also synthesized in stage 43 explants cultured without $T_{3}$, but at low levels (Fig. 5B). Because stage 43 larvae do not have a fully formed thyroid gland, these results strongly suggest that the initial activation of the $63-\mathrm{kD}$ keratin genes occurs in the absence of $\mathrm{T}_{3}$.

The inability of $\mathrm{T}_{3}$ to activate $63-\mathrm{kD}$ keratin synthesis prior to stage 48 and the responsiveness of larval skin to $\mathrm{T}_{3}$ treatment during stage 48 has also been demonstrated at the mRNA level. Larvae were treated with $T_{3}$ for 4 days from stages 37 to 47 , from stages 46 to 48 , or for 4 days during stage 48 . The $63-\mathrm{kD}$ keratin mRNAs were not detectable in the skin of embryos treated with $\mathrm{T}_{3}$ from stages 37 to 47 , from stages 46 to 48 / 1 day at stage 48 ), or in control embryos at early stage 48 . Large

Table 2. The developmental appearance of epidermal competence to respond to $T_{3}$

\begin{tabular}{lcc}
\hline \multicolumn{2}{c}{$\mathrm{T}_{3}$ treatment } & $\begin{array}{c}\text { Relative synthesis of } \\
\text { 63-kD keratins }\end{array}$ \\
\hline stages passed & time (days) & - \\
\hline $35-47$ (Fig. 5) & 4 & - \\
$33-47$ & 5 & \pm \\
$39-$ early 48 & 4 & \pm \\
$37-$ early 48 & 4 & + \\
$40-48$ & 5 & ++ \\
$40-48$ & 7 & ++ \\
$48-48$ & 4 & ++ \\
$41-48$ (Fig. 6) & 7 & +++ \\
$46-48$ (Fig. 6) & 7 & \\
\hline
\end{tabular}




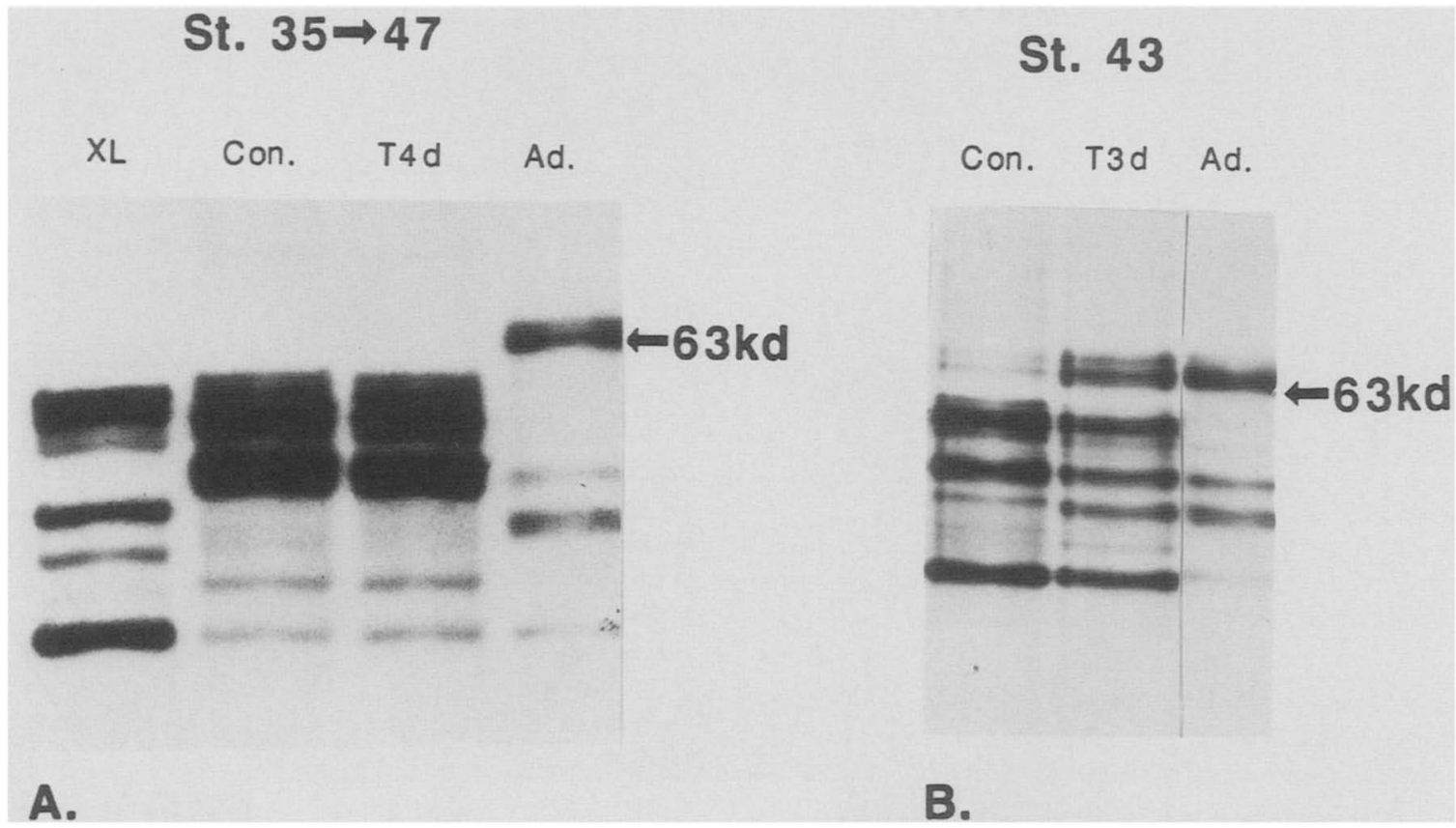

Figure 5. Induction of $63-\mathrm{kD}$ keratin synthesis in vivo and in vitro. $(A)$ Stage 35 larvae were treated with $T_{3}$ for 4 days until they reached stage 47 (T4d). Head skin from untreated, control larvae (Con) and $\mathrm{T}_{3}$-treated larvae was isolated and incubated with ${ }^{35} S$ )-methionine. (XL) A nonepidermal epithelial cell line that does not synthesize the 63-kD keratins; (Ad) adult epidermal keratins. $(B)$ Skin was isolated from stage 43 larvae and cultured in vitro for 6 days. (Con) Untreated cultures; (T3d) cultures treated for the last 3 days in vitro with $\mathrm{T}_{3}$ ( $\left.\mathrm{Ad}\right)$ adult epidermal cultures.

amounts of 63-kD keratin mRNA were present in larvae treated for 4 days with $\mathrm{T}_{3}$ during stage 48 (Fig. 7). Identical results were obtained using pM7 and pM14.

The results presented in this paper have demonstrated that $T_{3}$-independent and $T_{3}$-dependent steps are required for the full expression of the 63-kD keratin genes, but it is possible that individual $63-\mathrm{kD}$ keratin genes are not activated via a two-step process. Certain $63-\mathrm{kD}$ keratin genes may always be expressed at low levels independently of $T_{3}$ (beginning at stage 48), and others may be induced by $T_{3}$ (at stage 56 ) and account for high levels of expression. To demonstrate that an individual $63-\mathrm{kD}$ keratin gene is expressed at low levels in the absence of
$\mathrm{T}_{3}$ and that the same gene is responsive to $\mathrm{T}_{3}$-induction, gene-specific probes are required. The cDNA segments representing the 3 -nontranslated region of the $63-\mathrm{kD}$ keratin mRNAs are sufficiently different (Hoffmann et al. 1985) so that the transcripts of individual genes can be monitored with RNase protection mapping (Melton et al. 1984). The results of such an experiment are shown in Figure 8. Specific transcripts of the gene represented by pUF164 protect 458 nucleotides of the cRNA probe pM7. This gene is expressed at low levels in control stage 54 larval skin and skin explants grown in the absence of $T_{3}$, and the same gene is responsive to a 3-day $\mathrm{T}_{3}$ treatment in vivo and in vitro (Fig. 8).
Figure 6. Precocious $T_{3}$-induction of high-level 63-kD keratin synthesis. Larvae at stages 41 and 46 were treated with $T_{3}$ for 1 day, followed by 6 days without $T_{3}$ (T1d) or $T_{3}$-treated continuously for 7 days (T7d). At stage 48 the head skin of treated and untreated larvae was isolated and incubated with $\left[{ }^{35}\right.$ S]methionine.

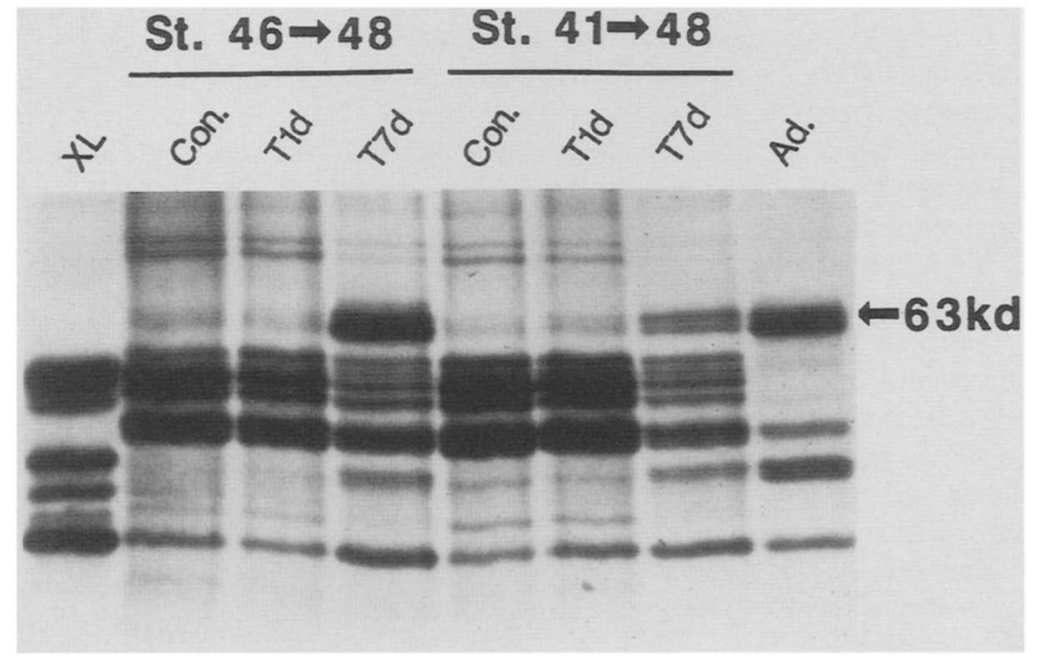




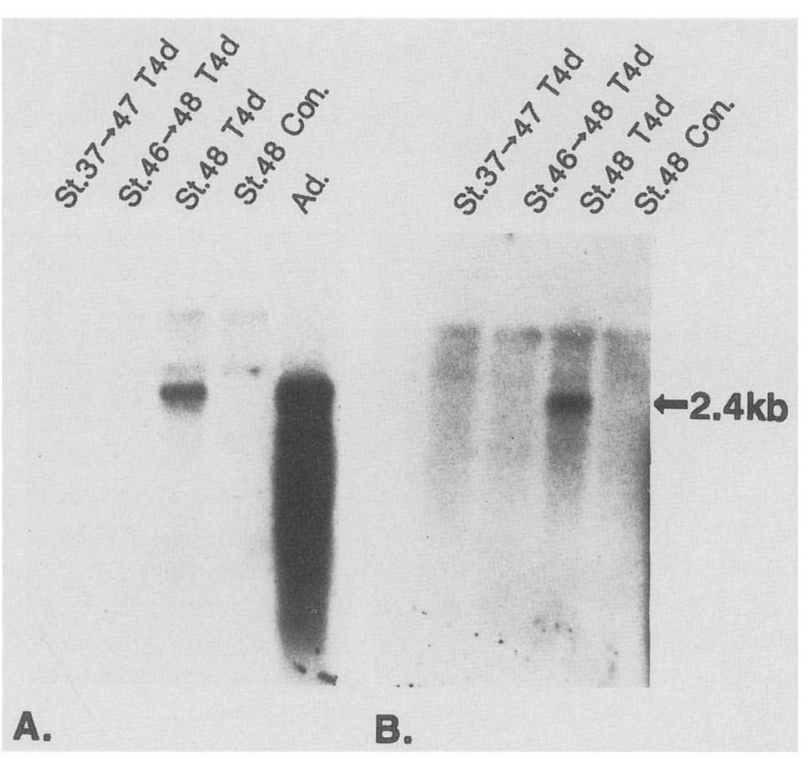

Figure 7. Precocious $\mathrm{T}_{3}$-induction of high levels of $63-\mathrm{kD}$ keratin mRNAs. Larvae were treated with $\mathrm{T}_{3}$ for 4 days from stages 37 to 47 , from stages 46 to 48 , or during stage 48 . RNA was isolated from the skin of treated and untreated larvae, electrophoresed, and blotted onto GeneScreen Plus filters. The filters were hybridized with a cRNA prepared from pM7 $(A)$ or pM14 $(B)$.

\section{Discussion}

During the development of the epidermis in Xenopus, the keratin genes are expressed in a strict temporal sequence. A unique set of embryonic and adult keratin genes is activated in succession. Embryonic keratins are initially expressed at the gastrula stage and disappear before metamorphosis (Sargent et al. 1987). Unlike the embryonic keratin genes, which are all activated within a few hours at the gastrula stage, the adult keratin genes are first expressed at different stages separated by many days (Ellison et al. 1985). The transcription of the embryonic keratin genes is controlled by cell autonomous factors probably inherited from the oocyte (Sargent et al. 1987), whereas transcription of the adult keratin genes appears to be regulated by external factors such as hormones. In this report we examine the role of the thyroid hormone $T_{3}$ in regulating the synthesis of the $63-\mathrm{kD}$ keratins and their mRNAs.

We have shown that full expression of the $63-\mathrm{kD}$ keratin genes requires two steps, one independent of $T_{3}$ and one dependent on $T_{3}$. A low-level leaky expression of the $63-\mathrm{kD}$ keratin genes begins at stage 48 . Our quantitative data indicate that less than 10 mRNA molecules per cell are present at this time. In different experiments, the first appearance of the $63-\mathrm{kD}$ keratins and mRNAs varied between stages 48 and 52 . We never observed 63-kD keratins or mRNA before stage 48 , and they were always present by stage 52 . At stage 56 a dramatic increase occurs in the expression of these genes. Quantitative analysis of the $63-\mathrm{kD}$ keratin mRNAs during the transition from low- to high-level expression (stage 52 to adult) demonstrated an increase greater than 1000-fold in the amount of mRNA. These results indicate that the changes observed in $63-\mathrm{kD}$ keratin synthesis are controlled at the mRNA level. Further experiments are necessary to determine whether the control resides primarily at the level of transcription and whether mRNA stability is changed by hormone treatment.

The initial activation of the $63-\mathrm{kD}$ keratin genes takes place at a time when thyroid hormones are not detectable in the larva, suggesting that they are not required for low-level activation of the keratin genes. Buscaglia et al. (1985) have shown that during Xenopus development, $\mathrm{T}_{4}$ is first detected at late stage 54 , and $\mathrm{T}_{3}$ at stage $57 />1$ month after stage 48). The concentrations of $T_{3}$ and $T_{4}$ then increase rapidly and reach their highest levels $\left(10^{-8}\right.$ M) during metamorphic climax at stages 60-62. Although thyroid hormones are not detectable in the bloodstream until stage 54, various results (for review, see Galton 1983) have suggested that the thyroid produces small amounts of hormones in premetamorphic larvae of some amphibian species. Ultrastructural studies of Xenopus larvae show that a definitive thyroid gland forms at stage 45 and that follicles containing colloid first appear at stage 46 (Jayatilaka 1978). It appears extremely unlikely, therefore, that low levels of thyroid hormone could be produced prior to stage 45 in Xenopus larvae. Even if undetectable, but low, levels of $T_{3}$ are produced between stages 46 and 56, it is unknown whether such small amounts of $T_{3}$ would have any effect on gene expression.

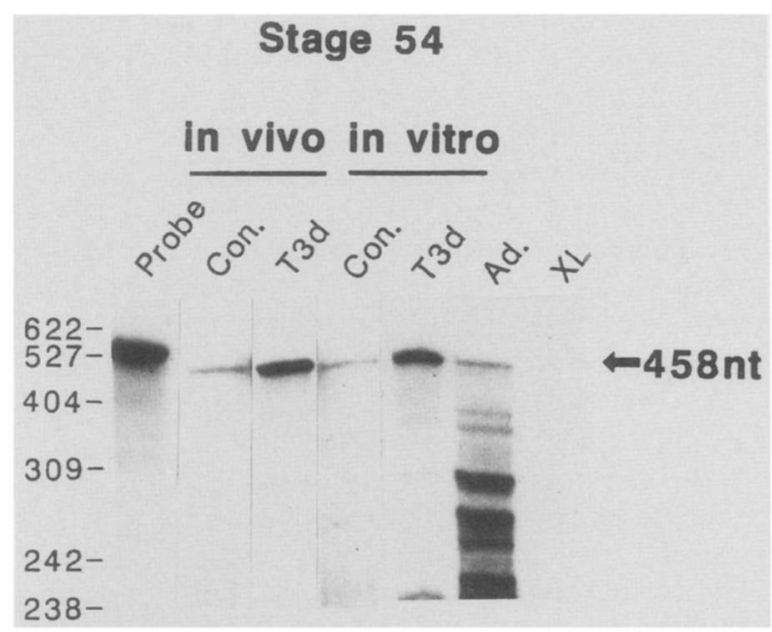

Figure 8. Analysis of specific gene transcripts by RNase protection mapping. ${ }^{32} \mathrm{P}$-Labeled cRNA prepared from pM7 was hybridized with RNA isolated from control and $\mathrm{T}_{3}$-treated larvae and skin cultures. Transcripts of the $63-\mathrm{kD}$ keratin gene represented by pUF164 protect a 458 -nucleotide region of the cRNA probe from RNase digestion. Transcripts of the other two genes (pUF132 and pUF23) protect $<100$ nucleotides. The unprotected cRNA probe is 523 nucleotides long. Markers are HpaIIcut pBR322. (Probe) Labeled pM7 antisense RNA used for hybridization; (Con) untreated larvae or skin cultures; (T3d) larvae or skin cultures treated for 3 days with $\mathrm{T}_{3}$ (Ad) adult epidermal RNA; (XL) XL-177 cell line RNA. Con lanes were exposed to film for $12 \mathrm{hr}$; Probe, T3, Ad, and XL lanes were exposed for $4 \mathrm{hr}$. 
To determine whether low levels of thyroid hormones are required for activation of the $63-\mathrm{kD}$ keratin genes, skin explants of larvae that had not yet developed a definitive thyroid gland were cultured with and without $T_{3}$. Low-level synthesis of the $63-\mathrm{kD}$ keratins and their mRNAs was observed in numerous experiments, where skin from stages 40-43 larvae was cultured without $T_{3}$ until the normal siblings reached stage 48 (Fig. 5B; P.M. Mathisen and L. Miller, in prep.). The simplest explanation for these results is that low-level expression of the 63-kD keratin genes in premetamorphic larval skin is not dependent on thyroid hormones. The finding that high concentrations of $\mathrm{T}_{3}$ do not induce the $63-\mathrm{kD}$ keratins or their mRNAs until stage 48 also supports the conclusion that the initial activation of these genes is independent of $\mathrm{T}_{3}$, that is, the $63-\mathrm{kD}$ keratin genes cannot respond to $T_{3}$ until after they have been activated at stage 48 . Clearly, stage 48 is a crucial period for the programming of the $63-\mathrm{kD}$ keratin genes, and future studies will focus on the cellular and molecular events that occur at this time. The receptors for thyroid hormones are initially detected at stages 36-40 (Tata 1968), so it is unlikely that their appearance is responsible for the inception of $T_{3}$ responsiveness in the epidermis at stage 48 .

The onset of high-level expression of the $63-\mathrm{kD}$ keratin genes is dependent on $T_{3}$. Two types of evidence support this conclusion. First of all, the onset of highlevel expression at stage 56 and the attainment of the adult level of expression are correlated with the rising concentrations of thyroid hormones in the blood (Buscaglia et al. 1985). Furthermore, the increased synthesis and accumulation of the $63-\mathrm{kD}$ keratins during metamorphic climax are also correlated with the $\mathrm{T}_{3}$-induced stratification and keratinization of epidermis (Nieuwkoop and Faber 1967). Second, high-level synthesis of the $63-\mathrm{kD}$ keratins and their mRNAs can be precociously induced at stage 48 , both in vivo and in vitro. Thus, all of the cellular factors required for high-level expression are present at stage 48 , even though highlevel expression does not normally begin until 1 month later at stage 56. Larvae treated for 3 months with PTU do not commence high-level synthesis, but if they are removed from the inhibitor they begin high-level synthesis when they reach stage 56 . Therefore, once stage 48 is reached, the induction of high-level $63-\mathrm{kD}$ keratin synthesis is dependent only on $T_{3}$, not on the age or the developmental stage of the embryo.

The results presented here suggest that $T_{3}$ induces a massive increase in the expression of genes that were previously activated and expressed at low levels. In a recent report on a cDNA library from Rana catesbeiana liver consisting of thyroid hormone-responsive genes, Lyman and White (1987) found five mRNAs that either increased or decreased in the presence of thyroid hormone but none that changed from unexpressed to expressed. Together, these results suggest that the basic mechanism by which $T_{3}$ induces differentiation during amphibian metamorphosis may be to modulate transcription of genes that were activated previously via a
$\mathrm{T}_{3}$-independent event, from a low basal level to a high constitutive level. Because pM7 recognizes all three 63-kD keratin mRNAs, we cannot be certain that all three genes are controlled by the same two-step process. We have shown by RNase protection mapping that one gene (represented by the cDNA pUF164) is expressed at low levels in the absence of $T_{3}$ and at high levels in the presence of $T_{3}$. Further RNase protection studies will be necessary to demonstrate that the other $63-\mathrm{kD}$ keratin genes are controlled in the same manner.

The presence of multiple cis-acting control elements, which are recognized by different trans-acting factors, appears to be a common mechanism for the regulation of several genes. Functional analysis of these elements has shown that the relative level of gene expression is controlled by the number, type, and arrangement of the elements combined with the presence, amount, and form of the factors (for review, see Maniatis et al. 1987). The two regulatory steps we have identified for the $63-\mathrm{kD}$ keratin genes may be part of a more complex regulation mediated by such regulatory elements and binding factors. Karin et al. (1987) have demonstrated the presence of distinct regulatory elements in the 5 '-flanking region of the human metallothionein gene that are required for basal level expression and induced (by heavy metals and glucocorticoids) high-level expression. A similar basalto high-level transcription of the cardiac actin gene has also been described by Minty et al. 1986. They found that the initial activation of the cardiac actin gene and its subsequent modulation to high-level expression are controlled by different trans-acting regulatory factors. Our results are compatible with such a model for the activation of the $63-\mathrm{kD}$ keratin genes. That is, after the $63-\mathrm{kD}$ keratin genes are activated by an event that is independent of $T_{3}$ and expressed at low levels, $T_{3}$ may induce the production of trans-acting modulatory factors that would control the high-level expression of the 63-kD keratin genes. As suggested by Brown (1984), gene activation (molecular commitment) may occur through the formation of an incomplete but stable transcription complex. The $\mathrm{T}_{3}$-induced modulatory factors would be required for the completion of a fully functional transcription complex allowing high-level gene expression.

Alternatively, as suggested for the rat growth hormone gene (Casanova et al. 1985; Crew and Spindler 1986), the $\mathrm{T}_{3}$ receptor complex itself may induce high-level expression of previously activated tissue-specific genes by binding to cis-acting regulatory sequences of these genes. If so, the high-level induction of the $63-\mathrm{kD}$ keratin genes by $T_{3}$ may be dependent on an increase in $T_{3}$ receptors. It has been demonstrated that $T_{3}$ increases the synthesis of its receptor, and it has been suggested that such an increase is required for the metamorphic actions of $\mathrm{T}_{3}$ (Galton 1984; Moriya et al. 1984). Further analysis of the developmental activation of the $63-\mathrm{kD}$ keratin genes may enable us to identify the components mediating the two levels of expression and to establish whether the $\mathrm{T}_{3}$-receptor complex acts on regulatory genes, tissue-specific genes, or both during amphibian metamorphosis. 


\section{Materials and methods}

\section{Keratin isolation and gel electrophoresis}

Cytoskeletal proteins were isolated from the head skin of larvae, as described previously (Ellison et al. 1985), after labeling proteins with $\left[{ }^{35} \mathrm{~S}\right]$ methionine $(100 \mu \mathrm{Ci} / \mathrm{ml}$; Amersham) for $4 \mathrm{hr}$. Keratins from larval and adult skin cultures (see below) and XL-177 cells were isolated using low and high salt buffers, according to Franke et al. (1981). The proteins were separated on SDS-polyacrylamide gels (Laemmli 1970), soaked in salicylic acid (Chamberlain 1979), dried, and exposed to X-ray film with an intensifying screen.

\section{Explant cultures}

Small pieces $\left(2 \mathrm{~mm}^{2}\right)$ of larval or adult skin were washed extensively in $\mathrm{Ca}^{2+} \mathrm{Mg}^{2+}$-free Barth's solution (Gurdon 1977) and plated on the surface of $35-\mathrm{mm}$ tissue culture dishes coated with a thin covering of Matri-gel (Collaborative Research). Cultures were grown at $25^{\circ} \mathrm{C}$ for 6 days in $70 \%$ Leibovitz media (GIBCO), containing $100 \mu \mathrm{g} / \mathrm{ml}$ gentamicin sulfate and 0.5 $\mu \mathrm{g} / \mathrm{ml}$ Amphotericin B (Sigma). Fetal calf serum was not used in these cultures. Where appropriate, $T_{3}$ (Sigma) was added to the media at $10^{-8} \mathrm{M}$ for the last 3 days of culture.

\section{Hybrid-selection and in vitro translation}

Total adult epidermal RNA was hybrid-selected with Xenopus keratin cDNAs and translated in a rabbit reticulocyte lysate (Ricciardi et al. 1979; Bautch et al. 1982). Plasmids containing inserts of keratin cDNAs $(1.5 \mu \mathrm{g})$ were boiled for $1 \mathrm{~min}$ and immobilized on a $0.5-\mathrm{cm}^{2}$ piece of nitrocellulose. The filters were then treated with $0.5 \mathrm{~N} \mathrm{NaOH}, 1.5 \mathrm{M} \mathrm{NaCl}$, followed by $2 \times$ SSC, $1 \mathrm{M}$ Tris ( $\mathrm{pH} 7.5)$ and, finally, with $2 \times$ SSC. The filters were allowed to air-dry and were then baked for $2 \mathrm{hr}$ at $80^{\circ} \mathrm{C}$ in vacuo. After soaking in $10 \mathrm{~mm}$ Tris (pH 7.5), 2 mM EDTA, the filters were cut into $1-\mathrm{mm}$ squares and placed in an Eppendorf tube. The hybridization buffer was $50 \%$ formamide, $750 \mathrm{mM}$ $\mathrm{NaCl}, 100 \mathrm{~mm}$ Tris (pH 7.5), and 2 mm EDTA. Epidermal RNA $(200 \mu \mathrm{g})$ was preheated at $65^{\circ} \mathrm{C}$ for $5 \mathrm{~min}$, cooled rapidly, and added to the hybridization buffer at $37^{\circ} \mathrm{C}$ for $4 \mathrm{hr}$. The buffer was removed and the filters washed 10 times each with $1-\mathrm{ml}$ aliquots of $10 \mathrm{~mm}$ Tris (pH 7.5), $150 \mathrm{~mm} \mathrm{NaCl}, 1 \mathrm{~mm}$ EDTA, and $0.1 \%$ SDS at $60^{\circ} \mathrm{C}$. The RNA was eluted by boiling the filters in $300 \mu \mathrm{l}$ of $1 \mathrm{~mm}$ EDTA for $1 \mathrm{~min}$, after the addition of $10 \mu \mathrm{g}$ of yeast tRNA, and then quick-chilled on dry ice-methanol. The RNA was ethanol-precipitated and dissolved in $1 \mu l$ of diethyl pyrocarbonate-treated $\mathrm{H}_{2} \mathrm{O}$. The RNA was translated, as described previously (Ellison et al. 1985).

\section{RNA isolation and blot procedures}

Epidermal RNA from swimming larvae was isolated by immersion for 2-4 min in $5 \mathrm{M}$ guanidine isothiocynate, $50 \mathrm{~mm}$ Tris $(\mathrm{pH} 7.5)$, and $5 \% \beta$-mercaptoethanol. This procedure results in lysis of the epidermis with minimal dermal contamination. RNA was then pelleted, as described previously /Chirgwin et al. 1979; Ellison et al. 1985). RNA from explant cultures was isolated in the same manner except that the guanidine solution was added directly to cultures. The lysate was then centrifuged at $40,000 \mathrm{rpm}$ for $16 \mathrm{hr}$ in an SW50.1 rotor. The purified RNA was stored under ethanol at $-70^{\circ} \mathrm{C}$.

Blot analysis of RNA was adapted from Hoffman et al. (1981) and the GeneScreen Plus Manual (New England Nuclear). Total epidermal RNA $(2-5 \mu \mathrm{g})$ was separated on $1.1 \%$ agarose, $20 \mathrm{~mm}$ sodium phosphate buffer $(\mathrm{pH} 6.8)$, and $3 \%$ formaldehyde gels. The gels were blotted onto GeneScreen Plus with $25 \mathrm{~mm}$ sodium phosphate buffer $(\mathrm{pH} 6.8)$, followed by baking at $80^{\circ} \mathrm{C}$ for $2 \mathrm{hr}$. The filters were agitated in prehybridization buffer $[50 \%$ formamide, $5 \times$ SSC, $5 \times$ Denhardt's solution, $100 \mu \mathrm{g} / \mathrm{ml} \mathrm{Esch-}$ erichia coli DNA, $20 \mu \mathrm{g} / \mathrm{ml}$ polyadenylic acid, $20 \mu \mathrm{g} / \mathrm{ml}$ yeast tRNA, 40 mM sodium phosphate buffer (pH 6.8), 0.5\% BSA, and $1.0 \% \mathrm{SDS}$ ] for $6 \mathrm{hr}$ at $65^{\circ} \mathrm{C}$. Hybridization was carried out with 32P-labeled cRNA probes (see below) in fresh hybridization buffer, which lacked BSA and contained $10 \%$ polyethylene glycol (Amasino 1986), for $16 \mathrm{hr}$ at $65^{\circ} \mathrm{C}$. The filters were washed twice in $2 \times$ SSC, $5 \mathrm{~mm}$ EDTA, $25 \mathrm{~mm}$ sodium phosphate buffer (pH 6.8), $1.5 \mathrm{~mm}$ sodium pyrophosphate, and $0.5 \%$ SDS for 15 min each at $65^{\circ} \mathrm{C}$. This was followed by a 1 -hr wash in a 20 -fold dilution of fresh first wash buffer at $65^{\circ} \mathrm{C}$. Filters were exposed to Kodak X-Omat X-ray film with an intensifying screen at $-70^{\circ} \mathrm{C}$. Transcript size was determined using RNA Ladder Markers (BRL). Slot blots were prepared using a Minifold II apparatus (Schleicher \& Schuell). Total RNA (1-5 $\mu \mathrm{g}$ ) was made $6 \%$ formaldehyde and $20 \mathrm{~mm}$ sodium phosphate $\mathrm{pH}$ 6.81, heated at $65^{\circ} \mathrm{C}$ for $25 \mathrm{~min}$, and cooled on ice. After making each sample $1 \mathrm{M}$ ammonium acetate, the RNA was slotted in a volume of $125 \mu$ l onto GeneScreen Plus that was presoaked in $1 \mathrm{M}$ ammonium acetate. Filters were allowed to air-dry overnight and were baked the next day at $80^{\circ} \mathrm{C}$ for $2 \mathrm{hr}$. Prehybridization and hybridization followed, as described above.

\section{RNA probes}

All the genes used in this study are cloned into the polylinker of the vector BlueScribe, $\mathrm{pBS}^{+}$(Stratagene).

pM7 A 458-bp BamHI fragment containing the 3 '-end $\beta$-turn and untranslated region of the Xenopus $63-\mathrm{kD}$ keratin cDNA, pUF164 (Hoffmann et al. 1985).

pM11 A 4.6-kb EcoRI fragment containing Xenopus rDNA sequences from pXlr11 (provided by Jeff Doering; see Dawid and Wellauer 1976).

pM12 A 330-bp BglII-PstI fragment containing the $\beta$-turn and the 3 -untranslated region of the Xenopus type-I keratin cDNA, pUF29 (Hoffmann and Franz 1984).

pM14 A 483-bp PstI fragment containing the conserved $\alpha$-helical region of pUF164.

In vitro-synthesized transcripts (cRNAs) are generated from linearized plasmids using $T_{3}$ RNA polymerase and the respective promoter as per manufacturer's instructions (Stratagene). Plasmids were linearized with EcoRI, except pMll, which was linearized with BglII. RNA probes were synthesized using $\left[\alpha^{-32} \mathrm{P}\right] \mathrm{CTP}$ at $20 \mathrm{mCi} / \mathrm{ml}$ (Amersham) and used immediately at $1 \times 10^{6} \mathrm{cpm} / \mathrm{ml}$ hybridization buffer.

\section{RNase mapping}

RNase protection experiments were conducted as described previously (Melton et al. 1984). The pM7-cRNA probe was generated as described above, except an additional $100 \mathrm{~mm}$ $\mathrm{NaCl}$ was included in the transcription buffer to avoid anomalous transcripts (Stratagene). Hybridization was done in $80 \%$ formamide, $40 \mathrm{mM}$ PIPES (pH 6.7), $0.4 \mathrm{M} \mathrm{NaCl}$, and $1 \mathrm{mM}$ EDTA for $5-6 \mathrm{hr}$ at $45^{\circ} \mathrm{C}$ after preincubation at $85^{\circ} \mathrm{C}$ for $10 \mathrm{~min}$. The hybridization mixture was then diluted $10 \times$ with the RNase solution [RNase A, $40 \mu \mathrm{g} / \mathrm{ml}$, and RNase T1 $(2 \mu \mathrm{g} / \mathrm{ml})]$ and in- 
cubated for $30 \mathrm{~min}$ at $30^{\circ} \mathrm{C}$. The digestion products were then analyzed by denaturing $6 \%$ acrylamide- $8 \mathrm{M}$ urea gel electrophoresis.

\section{RNA quantitation}

The amount of $63-\mathrm{kD}$ keratin mRNA was quantitated by using in vitro-synthesized sense RNA (Colbert et al. 1985; Harvey et al. 1986). Sense RNA transcripts were synthesized from pM7 using the $T_{7}$ promoter and RNA polymerase. The plasmid DNA was removed by digestion with RNase-free DNase (PromegaBiotec), and the RNA concentration determined spectrophotometrically. The transcripts were analyzed by agarose gel electrophoresis to ensure the absence of anomalous transcripts. Using a Minifold II apparatus, a dilution series (1 pg-1 ng) of sense RNA was immobilized onto a GeneScreen Plus filter. XL-177 RNA was used as a control for nonspecific binding of the probe, and all samples were made up to $1 \mu \mathrm{g}$ of total RNA by adding yeast tRNA to prevent mass-dependent binding (Colbert el al. 1985).

Filters containing a dilution series of sense RNA, adult RNA $(1 \mathrm{ng}-1 \mu \mathrm{g}$ ), and larval RNA of different stages were hybridized together with ${ }^{32} \mathrm{P}$-labeled antisense RNA transcribed from the $\mathrm{T}_{3}$ promoter of $\mathrm{pM} 7$. The resulting signal was quantitated by cutting the slots out of the filter and counting the radioactivity in a scintillation spectrometer and by scanning the X-ray film with a Hoefer GS300 densitometer. The concentration of $63-\mathrm{kD}$ keratin mRNA (pg of mRNA per $\mu g$ of total RNA) in adult and larval RNA was determined by comparing their relative levels of hybridization with values on a standard curve constructed with known amounts of pM7 RNA and taking into account the difference in size of the sense RNA (515 bp) and the 63-kD keratin mRNA $(2.4 \mathrm{~kb})$. In general, a 12-hr exposure to X-ray film with an intensifying screen produced a signal with $1 \mathrm{pg}$ of $\mathrm{pM} 7$ sense RNA and $1 \mathrm{ng}$ of adult epidermal RNA. This level of detection ( $<50$ molecules of mRNA per cell; see Table 1$)$ is comparable to that reported by Melton et al. (1984).

\section{Acknowledgments}

We are grateful to Dr. Werner Hoffmann for supplying pUF29, pUF164, and pUF23 and Dr. Jeff Doering for supplying the rDNA clone. We also thank Mr. Edward Touma for helping with the skin dissections and Ms. Margaret Kleist for typing the manuscript.

\section{References}

Amasino, R.M. 1986. Acceleration of neucleic acid hybridization rate by polyethylene glycol. Anal. Biochem. 152: 304307.

Bautch, V.L., R.V. Storti, D. Mischke, and M.L. Pardue. 1982. Organization and expression of Drosophila tropomyosin genes. J. Mol. Biol. 162: 231-250.

Brown, D.D. 1984. The role of stable complexes that repress and activate eucaryotic genes. Cell 37: 359-365.

Buscaglia, M., J. Leloup, and A. deLuze. 1985. The role and regulation of monodeiodination of thyroxine to 3,5,3'-triiodothyronine during amphibian metamorphosis. In Metamorphosis (ed. M. Balls and M. Bownes), pp. 273-293. Oxford University Press, New York.

Casanova, J., R.P. Copp, L. Janocko, and H.H. Samuels. 1985. 5 '-flanking DNA of the rat growth hormone gene mediates regulated expression by thyroid hormone. I. Biol. Chem. 260: $11744-11748$
Chamberlain, J.P. 1979. Fluorographic detection of radioactivity in polyacrylamide gels with the water-soluble fluor, sodium salicylate. Anal. Biochem. 98: 132-135.

Chirgwin, J.M., A.E. Przybyla, R.J. MacDonald, and W.J. Rutter. 1979. Isolation of biologically active RNA from sources enriched in ribonucleases. Biochemistry 18: 5294-5299.

Colbert, J.T., H.P. Hershey, and P.H. Quail. 1985. Phytochrome regulation of phytochrome mRNA abundance. Plant Mol. Biol. 5: 91-101.

Crew, M.D. and S.R. Spindler. 1986. Thyroid hormone regulation of the transfected rat growth hormone promoter. J. Biol. Chem. 261: 5018-5022.

Dawid, I.B. and P.K. Wellauer. 1976. A reinvestigation of $5^{\prime} \rightarrow 3^{\prime}$ polarity in $40 \mathrm{~S}$ ribosomal RNA precursor of Xenopus laevis. Cell 8: 443-448.

Dodd, M.H.I. and J.M. Dodd. 1976. The biology of metamorphosis. In Physiology of amphibia (ed. B. Lofts), vol. 3, pp. 467-599. Academic Press, New York.

Ellison, T.R., P.M. Mathisen, and L. Miller. 1985. Developmental changes in keratin patterns during epidermal maturation. Dev. Biol. 112: 329-337.

Franke, W.W., D.L. Schiller, R. Moll, S. Winter, E. Schmid, I. Engelbrecht, H. Denk, R. Krepler, and B. Platzer. 1981. Diversity of cytokeratins: Differentiation specific expression of cytokeratin polypeptides in epithelial cells. J. Mol. Biol. 153: 933-959.

Frieden, E. and J.J. Just. 1970. Hormonal responses in amphibian metamorphosis. In Biochemical action of hormones (ed. G. Litwack), vol. 1, pp. 2-52. Academic Press, New York.

Fuchs, E. and D. Marchuk. 1983. Type I and type II keratins have evolved from lower eukaryotes to form the epidermal intermediate filaments in mammalian skin. Proc. Natl. Acad. Sci. 80: 5857-5861.

Galton, V.A. 1983. Thyroid hormone action in amphibian metamorphosis. In Molecular basis of thyroid hormone action (ed. J.H. Oppenheimer and H.H. Samuels), pp. 445-483. Academic Press, New York.

- 1984. Putative nuclear triiodothyronine receptors in tadpole erythrocytes: Regulation of receptor number by thyroid hormone. Endocrinology 114: 735-742.

Gurdon, J.B. 1977. Methods for nuclear transplantation in amphibia. In Methods in cell biology (ed. G. Stein, J. Stein, and L.H. Kleinsmith), vol. 16, pp. 125-139. Academic Press, New York.

Harvey, R.P., C.J. Tabin, and D.A. Melton. 1986. Embryonic expression and nuclear localization of Xenopus homeobox (Xhox) gene products. EMBO J. 5: 1237-1244.

Hoffman, L.M., M.K. Fritsch, and J. Gorski. 1981. Probable nuclear precursors of preprolactin mRNA in rat pituitary cells. J. Biol. Chem. 256: 2597-2600.

Hoffmann, W. and J.K. Franz. 1984. Amino acid sequence of the carboxy-terminal part of an acidic type I cytokeratin of molecular weight 51,000 from Xenopus laevis epidermis as predicted from the cDNA sequence. EMBO J. 3: 1301-1306.

Hoffmann, W., J.K. Franz, and W.W. Franke. 1985. Amino acid microheterogeneity of basic (type II) cytokeratins of Xenopus epidermis and evolutionary conservativity of helical and non-helical domains. J. Mol. Biol. 184: 713- 724.

Jayatilaka, A.D.P. 1978. An ultrastructural study of the thyroid gland in the pre-metamorphic Xenopus laevis (Daudin) tadpole. I. Anat. 125: 579-591.

Karin, M., A. Haslinger, A. Heguy, T. Dietlin, and T. Cooke. 1987. Metal-responsive elements act as positive modulators of human metallothionein- $\mathrm{II}_{\mathrm{A}}$ enhancer activity. Mol. Cell Biol. 7: 601-613. 
Kollros, J.J. 1959. Thyroid gland function in developing coldblooded vertebrates. In Symposium on comparative endocrinology (ed. A. Gorbman), pp. 340-350. Wiley, New York.

Kollros, J.J. and J.C. Kaltenbach. 1952. Local metamorphosis of larval skin in Rana pipiens. Physiol. Zool. 25: 163-170.

Laemmli, U.K. 1970. Cleavage of structural proteins during the assembly of the head of bacteriophage T4. Nature 227: 680685.

Lyman, D.F. and B.A. White. 1987. Molecular cloning of hepatic mRNAs in Rana catesbieana responsive to thyroid hormone during induced and spontaneous metamorphosis. J. Biol. Chem. 262: 5233-5237.

Maniatis, T., S. Goodbourn, and J.A. Fischer. 1987. Regulation of inducible and tissue-specific gene expression. Science 236: $1237-1244$.

Melton, D.A., P.A. Krieg, M.R. Rebagliati, T. Maniatis, K. Zinn, and M.R. Green. 1984. Efficient in vitro synthesis of biologically active RNA and RNA hybridization probes from plasmids containing a bacteriophage SP6 promoter. Nucleic Acids Res. 12: 7035-7056.

Minty, A., H. Blau, and L. Kedes. 1986. Two-level regulation of cardiac actin gene transcription: Muscle-specific modulatory factors can accumulate before gene activation. Mol. Cell. Biol. 6: 2137-2148.

Moriya, T., C.R. Thomas, and E. Frieden. 1984. Increase in 3,5,3'-triiodothyronine $\left(T_{3}\right)$-binding sites in tadpole erythrocyte nuclei during spontaneous and $\mathrm{T}_{3}$-induced metamorphosis. Endocrinology 114: 170-175.

Neiuwkoop, P.D. and J. Faber. 1987. Normal table of Xenopus laevis (Daudin). North Holland, Amsterdam.

Reeves, R. 1977. Hormonal regulation of epidermis-specific protein and mRNA synthesis in amphibian metamorphosis. Dev. Biol. 60: 163-179.

Ricciardi, R.P., J.S. Miller, and B.E. Roberts. 1979. Purification and mapping of specific mRNAs by hybridization-selection and cell-free translation. Proc. Natl. Acad. Sci. 76: 49274931.

Sargent, T.D., E. Jonas, M. Jamrich, G.S. Michaels, S. Miyatani, J.A. Winkles, and I.B. Dawid. 1987. Cytokeratins and their genes in Xenopus laevis: Structural and developmental aspects. In Intermediate filaments (ed. R.D. Goldman and P.M. Steinert). Plenum Press, New York.

Tata, J.R. 1968. Early metamorphic competence of Xenopus laevis. Dev. Biol. 18: 415-440.

White, B.A. and C.S. Nicoll. 1981. Hormonal control of amphibian metamorphosis. In Metamorphosis: A problem in developmental biology (ed. L.I. Gilbert and E. Frieden), pp. 363-396. Plenum Press, New York. 


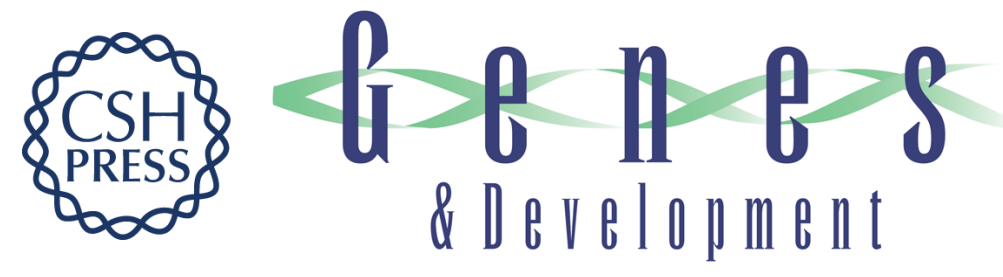

\section{Thyroid hormone induction of keratin genes: a two-step activation of gene expression during development.}

P M Mathisen and L Miller

Genes Dev. 1987, 1:

Access the most recent version at doi:10.1101/gad.1.10.1107

References This article cites 29 articles, 8 of which can be accessed free at:

http://genesdev.cshlp.org/content/1/10/1107.full.html\#ref-list-1

License

Email Alerting Receive free email alerts when new articles cite this article - sign up in the box at the top Service right corner of the article or click here.

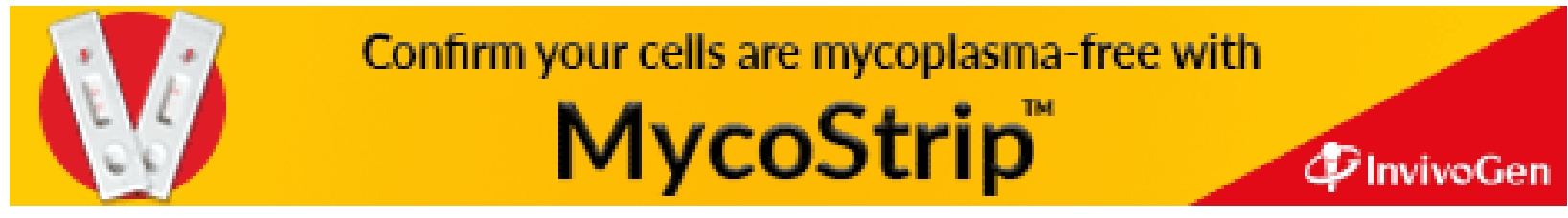

